Jurnal At-Tibyan: Jurnal Ilmu Alqur'an dan Tafsir

Volume 5 No. 2, Desember 2020 (h.194-212)

P ISSN 2442-594X | E ISSN 2579-5708

http://journal.iainlangsa.ac.id/index.php/tibyan

\title{
THE TRADITION OF WRITING MUȘḤ̂̄F AL-QUR'ĀN AKBĀR IN MUȘḤĀF AL-QUR'ĀN SCIENCES EDUCATION FOUNDATION (YPIIQ) WONOSOBO
}

\author{
Shofaussamawati \\ Institut Agama Islam Negeri Kudus, Indonesia \\ shofaussamawati@stainkudus.ac.id
}

Zahro Firdausa

Institut Agama Islam Negeri Kudus, Indonesia

firdausazahro@gmail.com

\begin{tabular}{|l|l|l|}
\hline \multicolumn{3}{|c|}{ DOI: $10.32505 /$ jurnal at-tibyan.v5i2.1303 } \\
\hline Submitted: 21-11-2019 & Revised: $14-06-2020$ & Accepted: 29-06-2020 \\
\hline
\end{tabular}

\begin{abstract}
:
The aim of this article is to describe the writing of Muṣhāf al-Qur'ān Sciences Education Foundation (YPIIQ) Wonosobo still written by hand in this sophisticated era. The type of this research uses the field research by a qualitative method approach which finds out the phenomenon and analyse the existing data. The process of collecting data uses interview, observation and documentation techniques, and it has found some interesting things. Firstly, the emergence of the tradition of writing Muṣhāf by hand and giant size departing from KH. Muntaha's idea, he is the caretaker of the Al-Asy'ariyyah Taḩfiż al-Qur'ān Islamic Boarding School, Kalibeber, Mojotengah, Wonosobo, Central of Java. The devotion of KH. Muntaha Al-Hafidz to alQur'ān made him to finally realise the grand Qur'ān writing project. KH. Muntaha al-Hafidz also wants to continue writing Al-Qur'ān that had been written by his grandfather, namely KH. Abdurrahim (1860-1916 AD). Secondly, before writing, there are certain provisions that must be carried out by writers namely they must be in a sacred condition when writing the muṣhāf, do the sunnah prayers of two raka'at and write it accompanied by fasting except several days that are forbidden to fast. Thirdly, the strong factor that encourages the tradition of writing muṣhāf at the Qur'ān Sciences Education Foundation (YPIIQ) Wonosobo is still being carried out till now because of devotion to teachers and wants to always glorify the muṣhāaf.
\end{abstract}

Keywords: Living Qur'an, Traditions, Writing Muṣhāf al-Qur'ān

Hak Cipta @ 2020. Dimiliki oleh Penulis, dipublikasikan oleh Jurnal At-Tibyan: Jurnal Ilmu Alqur'an dan Tafsir.

Artikel dengan akses terbuka. Lisenci: CC-BY 


\begin{abstract}
Abstrak:
Artikel ini bertujuan untuk mengetengahkan penulisan Muṣhāf al-Qur'ān di Yayasan Pendidikan Ilmu-ilmu Al-Qur'ān (YPIIQ) Wonosobo yang masih tetap ditulis dengan tangan di zaman yang canggih sekarang ini Artikel hasil penelitian ini menggunakan jenis penelitian lapangan (field research) dengan pendekatan metode kualitatif yakni metode untuk mengetahui fenomena dan menganalisis data yang ada. Metode pengumpulan data dengan teknik wawancara, observasi dan dokumentasi. Hasil penelitian ini menunjukkan bahwa pertama, hadirnya tradisi menulis Muṣhāf al-Qur'ān dengan tangan dan berukuran raksasa ini berawal dari ide KH. Muntaha Al-Hafidz, beliau adalah pengasuh Pondok Pesantren Taḥfiż al-Qur'ān (PPTQ) Al-Asy'ariyyah, Kalibeber, Mojotengah, Wonosobo, Jawa Tengah. Kecintaan KH. Muntaha AlHafidz terhadap al-Qur'ān yang menjadikan terealisasikannya proyek penulisan muṣhāa al-Qur'ān akbār. KH. Muntaha al-Hafidz juga ingin melanjutkan penulisan al-Qur'ān yang sudah pernah ditulis oleh kakeknya, yaitu KH. Abdurrahim (1860-1916 M). Kedua, Sebelum melakukan penulisan, ada ketentuan tertentu yang harus dilakukan oleh tim penulis yaitu harus dalam keadaan suci saat menulis al-Qur'ān, kemudian melakukan shalat sunnah dua rakaat dan saat menulis diiringi dengan berpuasa kecuali hari-hari yang diharamkan untuk berpuasa. Ketiga, faktor kuat yang mendorong tradisi penulisan muṣhāf al-Qur'ān akbār di Yayasan Pendidikan Ilmu-Ilmu Al-Qur'an (YPIIQ) Wonosobo masih dilakukan hingga sekarang adalah karena keta'dziman terhadap guru dan ingin selalu memuliakan al-Qur'ān.
\end{abstract}

Kata Kunci: Living Qur'an, Tradisi, Penulisan Muṣhāf al-Qur'ān

\title{
Pendahuluan
}

Sejarah mencatat bahwa kajian terhadap al-Qur'ān telah tumbuh dan berkembang sejak masa awal pertumbuhan dan perkembangan Islam. Baik itu dari aspek penghafalan, penulisan, pembukuan, pemahaman atau penafsiran terhadap al-Qur'ān sebagai bagian dari pemeliharaan al-Qur'an sehingga keotentikan al-Qur'ān tetap terpelihara. ${ }^{1}$

Gagasan untuk mengumpulkan al-Qur'ān (dalam bentuk tulisan) datang dari Umar ibn al-Khațtab setelah perang Yamamah yang banyak menelan korban dari kalangan ḩafiż dan qari' al-Qur'ān. Umar mengkhawatirkan akan hilangnya al-Qur'ān disebabkan para huffä̇ dan qurrā' banyak yang tewas dalam peperangan tersebut. ${ }^{2}$ Sahabat Umar mengusulkan kepada sahabat Abu Bakar untuk menuliskan al-Qur'ān. Setelah berdikusi cukup alot, akhirnya Abu Bakar menyetujui usul tersebut dan berkata Zaid ibn Sabit, salah seorang sahabat penulis wahyu terkemuka. Lalu dikumpulkannya al-Qur'ān dari benda-benda yang pernah ditulis di atasnya ayat-ayat al-Qur'ān pada masa Nabi seperti dari kulit binatang, pelepah kurma, dan lain-lain. Begitu juga dari hafalan para sahabat dan tulisan al-Qur'ān yang ada pada mereka. Zaid tidak akan

\footnotetext{
${ }^{1}$ Munzir Hitami, Pengantar Studi Al-Qur'an: Teori dan Pendekatan (Yogyakarta: LKiS, 2012), 20.

${ }^{2}$ Hitami, Pengantar, 23-24.
} 
menuliskan kecuali hal tersebut betul-betul ayat Al-Qur'ān yang dahulu pernah diajarkan oleh Rasulullah kepada para sabatnya. Setelah selesai barulah ia dinamakan "Muṣhāfo".

Seiring berjalannya waktu, muṣhāf al-Qur'ān semakin mengalami perbaikan seperti pemberian tanda baca, penomoran surat, tanda waqaf, tanda ayat sajadah, dan lain sebagainya. Muṣhāf al-Qur'ān disalin untuk diperbaiki, dari mulai masa sahabat, tabi'in, tabi'in tabi'in hingga sampai masa sekarang.

Di Indonesia sendiri perkembangan penerbitan muṣhāf cukup menggembirakan, mulai dari Muṣhāē Sundawi dari Jawa Barat, ${ }^{4}$ Muṣhāa Jakarta, Muṣhāf at-Tin, dan masih banyak lainnya. Semuanya itu membuktikan kecintaan kaum Muslimin di seluruh dunia terhadap al-Qur'ān al-Karīm. ${ }^{5}$

Penulisan ataupun penyalinan al-Qur'ān merupakan salah satu pengalaman interaksi kaum Muslim dengan al-Qur'ān. Penyalinan muṣhạa di Indonesia terutama di periode tulisan tangan bertujuan sebagai pelestarian al-Qur'ān mulai dari penyampaian, penghafalan, penulisan, standarisasi, dan pencetakan. Selain itu, motif lain dari penyalinan al-Qur'ān adalah untuk dakwah, yaitu mencoba melakukan interaksi sosial antara budaya dan teks al-Qur'ān. Sehingga wajar, bila masing-masing muṣhāf menyimpan pesan tersendiri, seperti cita-cita kerajaan, kondisi geografis Indonesia, adat-istiadat masing-masing daerah, dan lain sebagainya. ${ }^{6}$

Penelitian tentang penulisan al-Qur'ān sudah dihasilkan oleh beberapa peneliti. Diantaranya artikel berjudul Muṣhāf al-Qur'ān Nusantara: Perpaduan Islam dan Budaya Lokal oleh Lenni Lestari. ${ }^{7}$ Dalam kesimpulannya dsebutkan bahwa penyalinan dan pencetakan muṣhāf al-Qur'ān di Indonesia merupakan salah satu bentuk living Qur'an yang masih mempertahankan karakteristik budaya lokal dan dimungkinkan akan terus berkembang. Artikel lain berjudul Pencetakan muṣhāf al-Qur'ān di Indonesia oleh Ali Akbar berjudul Pencetakan muṣhāe al-Qur'ān di Indonesia, menguraikan perkembangan pencetakan muṣhāf al-Qur'ān di Indonesia sejak masa awal pertumbuhannya pada pertengahan abad ke-19 hingga dewasa ini dan pengaruh muṣhāf al-Qur'ān cetakan India dan Turki dalam masa awal pencetakan muṣ̣āa di Indonesia ${ }^{8}$

Tulisan Enang Sudrajat berjudul Pentashihan muṣhạf al-Qur'ān di Indonesia menjelaskan bahwa untuk menjaga kesahihan muṣhāf al-Qur'ān dilakukan dalam bermacam cara, di antaranya pemerintah membentuk Lajnạ Pentaṣhịịān muṣhāa al-

\footnotetext{
${ }^{3}$ Departemen Agama RI, Mukadimah Al-Qur'an dan Tafsirnya (Jakarta: Departemen Agma RI, 2008), 14.

${ }^{4}$ Aam Abdillah Billy Muhammad Rodibillah, Ajid Thohir, "Sejarah Penulisan Al-Qur'an Mushaf Sundawi Di Bandung Tahun 1995-1997," Historia Madania Jurnal Ilmu Sejarah 2, no. 2 (2018): $25-52$.

${ }^{5}$ Departemen Agama RI, Mukadimah Al-Qur'an dan Tafsirnya, 17.

${ }^{6}$ Lenni Lestari, “Mushaf Al-Qur'an Nusantara: Perpaduan Islam Dan Budaya Lokal," Jurnal AtTibyan:Jurnal Ilmu Alqur'an dan Tafsir 1no. 1 (2016): 173-198.

${ }^{7}$ Lestari, 173-198.

${ }^{8}$ Ali Akbar, "Pencetakan Mushaf Al-Qur'an di Indonesia," SUHUF 4 no.1 (2011), https://www.researchgate.net/publication/305143831_Pencetakan_Mushaf_Al-Qur'an_di_Indonesia full Text FileContent .
} 
Qur'ān untuk mentaṣhịh semua muṣhāf yang akan dicetak dan usaha lainnya dilakukan oleh masyarakat muslim melalui pesantren, kajian, dan taḥfiż al-Qur'ān. ${ }^{9}$

Di dalam artikel ini diuraikan penulisan muṣhạâf al-Qur'ān di Yayasan Pendidikan Ilmu-Ilmu Al-Qur'an (YPIIQ) Wonosobo yang masih tetap ditulis dengan tangan di zaman yang canggih sekarang ini dan belum pernah dilakukan oleh penulis sebelumnya. Mengapa penulisan secara manual dengan tangan asli tanpa menggunakan alat cetak yang canggih saat ini dilakukan, apa motivasinya menjadi sangat menarik untuk dikaji.

\section{Sejarah Pemeliharaan dan Penulisan Al-Qur'ān dari Masa ke Masa}

\section{Pemeliharaan dan Penulisan Al-Qur'ān Masa Nabi}

Pada masa Rasulullah ayat al-Qur'ān yang turun dihafal oleh beliau. Seperti firman Allah SWT QS. Al-Qiyamah ayat 17:

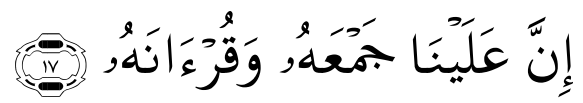

Terjemah: "Sesungguhnya atas tanggungan Kamilah mengumpulkannya (di dadamu) dan (membuatmu pandai) membacanya"10

Oleh karena itu beliau merupakan hafidz (penghafal) al-Qur'ān yang pertama dan maha guru pemberi contoh panutan paling baik bagi para sahabat dalam menghafalnya. ${ }^{11}$

Pada mulanya, bagian-bagian al-Qur'ān yang diwahyukan kepada Rasulullah dipelihara dalam ingatan Nabi dan para sahabatnya. Tradisi hafalan yang kuat di kalangan masyarakat Arab telah memungkinkan terpeliharanya al-Qur'ān dalam cara semacam itu. Jadi, setelah menerima suatu wahyu, Rasulullah menyampaikannya kepada para pengikutnya, yang kemudian mengahafalnya. Sejumlah hadits menjelaskan berbagai upaya Rasulullah dalam merangsang penghafalan wahyu-wahyu yang telah diterimanya. Salah satu di antaranya adalah yang diriwayatkan oleh 'Usman bin Affan bahwa Rasulullah pernah bersabda: "Yang terbaik di antara kamu adalah mereka yang memepeajari al-Qur'ān dan kemudian mengajarkannya". ${ }^{2}$

Kemudian cara selanjutnya yang dilakukan dalam pemeliharaan al-Qur'ān di masa Nabi adalah perekaman dalam bentuk tertulis unit-unit wahyu yang diterima Nabi. ${ }^{13}$ Setelah menerima wahyu, Rasulullah mengumumkannya di hadapan para sahabat dan memerintahkan mereka untuk menghafalnya. Para sahabat selanjutnya diriwayatkan telah "mengumpulkan" al-Qur'ān dari Rasulullah dengan cara yang sangat komprehensif.

\footnotetext{
${ }^{9}$ Enang Sudrajat, “Pentashihan Mushaf Al-Qur'an Di Indonesia," SUHUF6 (2013).

${ }^{10}$ Q.S. Al-Qiyamah [75]: 17

${ }^{11}$ Suhadi, Ulumul Qur'an (Kudus: Nora Media Enterprise, 2011 ), 25.

12 Taufik Adnan Amal, Rekonstruksi Sejarah al-Qur'an (Jakarta: Pustaka Alvabet, 2005), 150-151.

${ }^{13}$ Amal, 151.
} 
Alat tulis dan media tulis ketika itu memang masih sulit, sehingga mereka menggunakan media seadanya seperti lempengan batu, tulang binatang, kulit kayu, pelepah kurma, dan lain sebagainya.

\section{Kompilasi Al-Qur'ān di Masa Kekuasaan Abu Bakar}

Setelah Rasulullah wafat, Abu Bakar terpilih sebagai khalifah. Saat itu hampir seluruh kabilah-kabilah Arab kembali Murtad secara politik dan sebagian membangkang menolak membayar zakat, karena mereka mengira kekuatan Islam sudah pudar setelah meninggalnya Rasulullah. Untuk mengatasi kemurtadan politik dan pembangkangan kabilah-kabilah Arab itu, Khalifah Abu Bakar mengirimkan pasukan untuk menundukkan mereka dan menyeru kembali kepada Islam yang dikenal sebagai "perang riddah". Di samping itu di daerah Yamamah - Arab Selatan - muncul Musailamah al-Khazab - sang pendusta - yang mengaku sebagai Nabi. Khalifah Abu Bakar memeranginya yang dikenal sebagai "perang Yamamah". Pada berbagai peperangan tersebut banyak qari' dan pengahafal Al-Qur'ān dari kalangan sahabat yang gugur. Umar bin Khattab - sebagai penasihat Abu Bakar - merasa khawatir AlQur'ān akan punah bersama banyaknya para qari' yang gugur tersebut. Umar bin Khattab mengusulkan agar Al-Qur'ān dikumpulkan dalam satu Muṣhāe .

Riwayat yang panjang yang diambil oleh Abu Bakar, khalifah setelah Nabi, dan Umar bin Khattab dapat ditemukan pada sebuah hadits yang ada dalam koleksi Bukhari, dan diceritakan oleh Zaid bin Tsabit, yang dikenal sebagai penullis wahyu yang paling menonjol:

"Abu Bakar mendatangiku setelah jatuhnya banyak korban Yamamah. Umar datang bersama Abu Bakar yang berkata: "Umar mendatangiku dan berkata: 'Banyak korban jatuh pada perang Yamamah dan aku khawatir akan ada banyak korban dari kalangan para pembaca Al-Qur'ān di tempat lain, yang dengannya sebagia besar Al-Qur'ān akan hilang, kecuali jika engkau mengumpulkannya. Aku berpendapat bahwa engkau harus mengumpulkan AlQur'ān ." Abu Bakar menambahkan: “ Aku berkata pa Umar: 'Bagaimana seseorang bisa melakukan sesuatu yang tidak dilakukan Rasulullah?' Umar berkata kepadaku: 'Demi Allah, ini (memang) perbuatan yang baik.' Umar terus mendesak, berusaha meyakinkanku untuk menerima usulannya, hingga Allah membukakan dadaku da aku berpendapat seperti Umar."

Umar duduk di sebelahnya (Abu Bakar) dan tidak berkata apapun. Abu Bakar berkata kepadaku: "Engkau adalah pemuda yang bijaksana dan kami yakin engkau tidak pernah mengatakan kebohongan ataupun lupa; engkau terbiasa menuliskan wahyu untuk Rasul. Karena itu, carilah Al-Qur'an dan kumpulkan (dalam satu manuskrip). "Demi Allah, jika Abu Bakar memerintahkan padaku untuk membalik salah satu gunung maka itu tidaklah lebih berat dari perintahnya untuk mengumpulkan Al-Qur'ān . Aku berkata padanya: “ Bagaimana mungkin engkau berani melakukan hal yang tidak dilakukan Nabi?" Abu Bakar berkata: "Demi Allah, ini adalah hal yang baik."

Lalu aku terus mendebatnya sampai Tuhan membukakan dadaku sebagaimana ia telah membuka dada Abu Bakar dan Umar. Maka aku mencari bahan-bahan al-Qur'ān dan mengumpulkannya dari perkamen-perkamen, daun kering dari 
pohon kurma, dan dari hafalan orang-orang. Bersama Khuzaimah aku menemukan dua ayat dari surat at-Taubah (surat yang diberi nama "ampunan") yang tidak aku temukan pada orang-orang lain yakni" Telah datang padamu seorang Rasul dri bangsamu sendiri, yang menanggung beratnya derita sebagaimana kamu...." (QS. 9: 12)."14

Muṣhāf -muṣhāf yang telah terkumpul lalu disimpan di rumah Khalifah Abu Bakar hingga beliau wafat. Muṣhāf -muṣhạa ini kemudian dipindahkan dan disimpan di rumah Khalifah Umar hingga beliau wafat. Terkahir, muṣhāa -muṣhāf ini disimpan di rumah ummul-mukminin Hafshah, sesuai wasiat dari Khalifah Umar. Para ulama berpendapat bahwa penamaan Alquran dengan 'mushaf' itu baru muncul sejak pembukuan al-Qur'an pada masa Khalifah Abu Bakar. Ali ra. berkata,"Orang yang paling besar pahalanya dalam hal mushaf ialah Abu Bakar ra. Semoga Allah melimpahkan rahmat-Nya kepada Abu Bakar ra. Dialah orang yang pertama mengumpulkan kitab Allah. ${ }^{15}$

\section{Pemeliharaan Al-Qur'ān pada Masa 'Usman Ibn Affan}

Pada masa 'Usman Ibn Affan pada tahun $25 \mathrm{H}$. Sebabnya adalah perbedaan kaum muslimin pada dialeg bacaan al-Qur'ān sesuai dengan perbedaan muṣhāa -muṣhāf yang ada di tangan para sahabat. ${ }^{16}$

Perlu dikemukakan di sini bahwa para sahabat yang mendapatkan bacaan dari Nabi mengajarkan bacaan tersebut kepada para murid mereka di negeri yang dikuasai oleh kaum Muslimin. Penduduk Kufah memperoleh bacaan mereka dari Ibnu Mas'ud, sementara penduduk Syria memperolehnya dari Abu Darda', Penduduk Basrah dari Abu Musa al-'Asy'ari, dan penduduk lainnya dari sahabat yang lainnya. Di antara bacaan tersebut terdapat banyak perbedaan. Sampai pada saat peperangan di Azerbaijan dan Armenia terjadi perselisihan antara orang Irak dan Syam dalam hal pembacaan al-Qur'ān sebagaimana yang terjadi pada masa Nabi. Mereka belum tahu tentang diperbolehkannya membaca al-Qur'ān dengan berbagai macam versi sebagaimana hadis "al-Ahrüf as-Sab'äh".

Inilah yang menyebabkan sahabat Usman Ibn Affan mempunyai prakarsa untuk menulis kembali naskah al-Qur'ān dengan tujuan untuk membuat muṣhāf induk. Tujuannya adalah untuk mempersatukan muṣhāf (tauhīd al-maṣāhîf). Mengingat banyak kaum Muslimin yang mempenyai muṣhāa pribadi. Dalam muṣhāf pribadi tidak menutup kemungkinan ada yang bercampur dengan penafsiran, atau ada kesalahan dalam penulisan al-Qur'ān, atau juga memasukkan sesuatu yang bukan al-Qur'ān ke dalamnya.

Sahabat "Usman Ibn Affan lalu membentuk "lajnah" atau tim penulis muṣhāaf. Muṣhāf yang pernah ditulis pada masa Abu Bakar yang masih tersimpan dengan baik

\footnotetext{
${ }^{14}$ Farid Esack, Samudera al-Qur'an (Yogyakarta: DIVA Press, 2007), 154-155.

${ }^{15}$ Nasruddin, "Sejarah Penulisan Alquran (Kajian Antropologi Budaya)" Jurnal Rihlah 2 no. 1 (Mei 2015): 53-68, https://doi.org/10.24252/rihlah.v2i01.1360

${ }^{16}$ Nur Efendi dan Muhammad Fathurrohman, Studi Al-Qur'an: Memahami Wahyu Allah secara Lebih Integral dan Komprehensif (Yogyakarta: Teras, 2014), 106.
} 
di rumah Siti Hafsah, istri Nabi dan putri 'Umar ibn al-Khattāb merupakan sumber utama dalam penulisan muṣhāf pada masa ini. Selain itu, Usman juga berusaha mencari bahan dari hafalan dan tulisan para sahabat. Sahabat 'Usman memberikan pengarahan kepada tim penulis muṣhāf khususnya dari kalangan Muhajirin dengan berkata, "Jika kamu berbeda dalam menulis sesuatu ayat al-Qur'ān dengan Zaid ibn al-Sabit, maka tuliskanlah dengan bacaan yang sesuai dengan bacaan kaum Quraisy, karena al-Qur'ān pertama kali diturunkan dengan bahasa (lisan) Quraisy". Setelah muṣhāf ditulis, sahabat 'Usman mengembalikan muṣhāf yang ditulis pada masa Abu Bakar kepada Siti Hafsah dan memerintahkan kepada kaum Muslimin untuk membakar muṣhāf yang ada pada mereka. Dengan selesainya al-Qur'ān ditulis kembali, kaum Muslimin mempunyai muṣhāf induk (master) atau yang disebut dengan Muṣhā f al-Imam. ${ }^{17}$

Para pencatat wahyu yang terdokumentasi di kalangan ahli sejarah berjumlah 26 orang sahabat. Sedangkan dari sirāh al-irāqī yang mengutip pendapat al-Halabi dan dikutip Kalimatul 'Ulya dan Saidah para penulis wahyu berjumlah 44 orang sahabat. ${ }^{18}$

\section{Penyempurnaan Penulisan Al-Qur'ān Setelah Masa Khalifah}

Sejak adanya muṣhāf 'Usmani yang merupakan hasil karya khalifah 'Uśman Ibn Affan dengan timnya, para sahabat dan kaum muslimin menjadi memiliki satu muṣhāf yang menjadi pedoman dalam bacaan maupun dalam tulisan al-Qur'ān. Penyalinan terus dilakukan berdasarkan kebutuhan. Para sahabat dan umat yang merasa harus memiliki muṣhāf al-Qur'ān yang teliti dan tertib banyak yang turut menelitinya. ${ }^{19}$

Sebagaimana diketahui muṣhāf yang telah terwujud di era 'Usman belum ada tanda bacanya, baik itu harakat dan tanda titik yang memiliki peluang untuk dibaca dengan salah satu qira'at yang tujuh. Di kalangan orang non-Arab pada awal masuk Islam, mereka mengalami kesulitan dalam membaca muṣhāa tersebut. ${ }^{20}$

Pada masa berikutnya, yaitu pada masa Bani Umayyah, yaitu pada masa Khalifah Mu'awiyyah ibn Abi Sufyan dirasakan perlunya memberi tanda baca, mengingat kendala yang dihadapi orang non-Arab yang memeluk Islam dalam membaca muṣhāf tersebut. Ditunjuklah seorang yang bernama Abu al-Aswad ad-Du'ali (w. 69H) untuk melakukan hal ini. Abu al-Aswad menunjuk seorang dari suku 'Abdul Qais atau dari suku Quraisy yang akan bertindak mencantumkan tanda baca pada muṣhāf, sementara Abu al-Aswad mendiktekan. Lalu dilakukanlah pemberian tanda baca dengan memberi titik pada huru-huruf akhir pada setiap kalimat. Titik di atas huruf berarti fathăh, titik di bawah huruf berarti kasrāh, titik di depan huruf berarti dammāh, dua titik berarti tanwin, dan seterusnya. Tinta yang digunakan untuk memberi titik berbeda dengan warna untuk menulis muṣhāf.

\footnotetext{
${ }^{17}$ Departemen Agama RI, Mukadimah Al-Qur'an, 15-16

${ }^{18}$ Kalimatul 'Ulya dan Saidah, "Rijalul Qur'an : Membincang Sejarah Para Penulis Wahyu", QOF 1 no. 1 (Januari 2017): 51-64. https://doi.org/10.30762/qof.v1i1.929

${ }^{19}$ Abdul Chaer, Perkenalan Awal dengan Al-Qur'an (Jakarta: Rineke Cipta, 2014), 106.

${ }^{20}$ Efendi dan Fathurrohman, Studi Al-Qur'an, 107-108.
} 
Pemberian titik pada huruf-huruf semisal, seperti antara huruf $b a^{\prime}, s a^{\prime}$, dan $t a^{\prime}$. Antara jim , ha', dan kha' dan seterusnya dilakukan era selanjutnya, masih pada masa tabi'in, lebih tepatnya pada masa Abd al-Malik ibn al-Marwan.

Kemudian Imam Khalil ibn Ahmad al-Farahidi (w. 177H), guru Imam Sibawih (ahli nahwu), yang menyempurnakan titik yang pernah ditulis Abu al-Aswad ad-Du'ali menjadi harakat yang ada sekarang ini, yaitu harakat fatḥăh dengan alif miring. Harakat ḍammāh dengan wau kecil. Kasräḥ dengan ya' kecil yang dipangkas kepalanya. Tanda tasydid dengan kepala huruf sin. Sukun dengan kepala huruf kha' kecil, dan seterusnya.

Pada periode berikutnya, muṣhāf terus mengalami perbaikan seperti penomoran ayat, pemberian nama surah, jumlah ayat pada satu surah dan urutan turunnya, tanda waqaf, tanda ayat sajadah, pembagian al-Qur'ān menjadi 30 juz, dan setiap juz dibagi menjadi dua bagian yang sebagian dinamakan hizb. Setiap hizb manjadi empat bagian lagi, sehingga setiap juz terdapat delapan bagian (Sumun). Dengan begitu al-Qur'ān mempunyai 60 hizb dan 240 rub' yaitu 30 juz dikalikan delapan. Pembagian semacam ini adalah untuk memudahkan bagi pembaca atau penghafal al-Qur'ān. ${ }^{21}$

\section{Sejarah dan Perkembangan Muṣ̣̣āf Al-Qur'ān Nusantara}

Sekitar pada abad ke-13, penulisan al-Qur'ān di Nusantara ditengarai diawali dari Aceh, semasa Kerajaan Samudra Pasai kerajaan Islam tertua di Nusantara berada di tampuk pemimpinan Sultan Malik Saleh. Walaupun salinan muṣhāf al-Qur'ān khas Nusantara dari abad itu tidak ditemukan ada kemungkinan karena lekang sudah sangat lama atau sebab lainnya tapi dengan adanya kerajaan Islam, secara otomatis naskah alQur'ān menjadi prioritas utama.

Selanjutnya, penyalinan al-Qur'ān secara tradisional terlaksana sampai akhir abad ke-19 atau awal abad ke-20, yang dapat dijumapi di berbagai kota atau wilayah penting masyarakat Islam saat itu, seperti Aceh, Padang, Riau, Palembang, Banten, Cirebon, Yogyakarta, Surakarta, Madura, Lombok, Pontianak, Banjarmasin, Samarinda, Makasar, Ternate, dan lain-lain. ${ }^{22}$

Motivasi dakwah dan penyampaian ajaran al-Qur'ān menjadi pendorong dalam Penyalinan muṣhāf kuno sejak awal. Hal ini dapat difahami karena pada masa itu belum ada teknologi untuk penggandaan naskah dalam jumlah yang besar, semua naskah ditulis tangan. Tetapi di penghujung abad ke-19 M minat penulisan muṣhāf alQur'ān di Indonesia semakin berkurang. Bahkan diperkirakan pembuatan seni muṣhāf al-Qur'ān mulai berhenti di awal abad 20.

Ada tiga pihak yang lazimnya menjadi sponsor penulisan muṣhāf Indonesia, yaitu: kerajaan, pesantren, dan elite sosial. Pada zaman dulu, banyak muṣhāf yang ditulis oleh para ulama atau seniman atas perintah raja. Disamping itu, pesantren juga

\footnotetext{
${ }^{21}$ Departemen Agama RI, Mukadimah Al-Qur'an dan Tafsirnya, 16-17.

${ }^{22}$ Reza Pahlevi, "Dakwah Kultural Bayt Al-Qur'an Al-Akbar Ukiran Kayu Khas Melayu Palembang," Intizar 22, no. 1 (2016): 173-197, https://doi.org/10.19109/intizar.v22i1.548.
} 
memegang peranan penting dalam penulisan al-Qur'ān. Sebagai contoh, muṣhāf yang ada di pesantren Tegal Sari, Ponorogo, Jawa Timur, Pesantren Buntet di Cirebon, dan lain-lain. Adapun dari kalangan elit sosial seperti Muṣhāf Ibnu Sutowo dan terakhir muṣhāa at-Tin atas perintah HM Suharto, mantan persiden RI.

Penyalinan al-Qur'ān dilakukan oleh berbagai lapisan masyarakat Islam, baik para penyalin profesional, santri, maupun para ulama. Pada awal abad ke-19 Abdullah bin Abdul Kadir al-Munsyi termasuk orang yang awal-awal menyalin al-Qur'ān. Para santri di berbagai pesantren menyalin al-Qur'ān terutama untuk kepentingan pengajaran. Sementara, beberapa ulama terkenal juga dikatakan pernah menyalin alQur'ān. Penyalinan juga dilakukan oleh para ulama atau pelajar yang tengah memperdalam ilmu agama di Mekah. Pada abad ke16 sampai 19 M, Mekah selain berfungsi sebagai tempat menunaikan haji, juga merupakan pusat studi Islam. ${ }^{23}$

Perkembangan penulisan AlQurean di Indonesia telah lama berlangsung, sejak dari masa penulisan Al-Qur'an secara manual (manuskrip), litografi (cetak batu), sampai menggunakan mesin-mesin cetak modern yang dapat menghasilkan tulisan AlQur ${ }^{\text {ee }}$ an berjilid-jilid dalam waktu yang singkat seperti yang berkembang sekarang ini. ${ }^{24}$ Berdasarkan alur perkembangan, ada tiga periode perkembangan muṣhāf di Indonesia yaitu:

a. Muṣhāf tulis tangan

Teknik penyalinan Al-Qur'ān di Indonesia dimulai dari metode tulisan tangan. Periode ini sudah dimulai sejak abad ke-13 Masehi. Hasilnya sangat banyak dan saat ini tersimpan di beberapa museum, perpustakaan, pesantren, dan sebagainya. ${ }^{25}$

b. Mușhạaf cetak mesin

Asal-usul Qur'an cetakan awal (early printed Qur'an) yang beredar di Asia Tenggara pada paruh akhir abad ke-19 berdasarkan temuan hingga kini- tidaklah banyak. Pusat-pusat percetakan yang diketahui, yaitu Palembang, Singapura, Bombay, serta Turki. ${ }^{26}$

Perkembangan pencetakan muṣhāf kian pesat. Hal ini ditandai dengan munculnya variasi tampilan Muṣ̣āf al-Quran yang disesuaikan dengan segmen pembacanya, seperti anak-anak, wanita, pengkaji fiqh atau ushul fiqh, saintifik, dan lain sebagainya. ${ }^{27}$

c. Muṣhāaf digital

Muṣhāf digital banyak dikembangkan seiring dengan meningkatnya teknologi IT. Umumnya dikemas dalam bentuk visual dan audio, atau audio-visual. ${ }^{28}$

Perhatian dari segi keindahan penulisan mushaf al-Qur'an, baik itu dari konsep desain, khat, tatanan iluminasi, dan sebagainya dilakukan dalam penulisan dan

\footnotetext{
${ }^{23}$ Lestari, Mushaf Al-Qur'an Nusantara, 175-176.

${ }^{24}$ Billy Muhammad R, Ajid, Aam, "Sejarah Penulisan Al-Qur'an Mushaf Sundawi di Bandung Tahun 1995-1997”, Historia Madania 2 no. 2, (2018): 25-51. http://dx.doi.org/10.15575/hm.v2i2.9149

${ }^{25}$ Lestari, Mushaf Al-Qur'an Nusantara, 176.

${ }^{26}$ Lestari, 182 .

${ }^{27}$ Lestari, 188 .

${ }^{28}$ Lestari, 190 .
} 
pencetakan mushaf Al-Qur'an baik di dalam maupun luar Indonesia . Di Indonesia, perhatian terhadap keindahan mushaf ini telah berlangsung sejak awal penulisan mushaf-mushaf kuno, hingga saat ini masih terus berlanjut, dipertahankan, dan menjadi ciri khas. ${ }^{29}$

Pada dekade akhir abad ke-20, di Indonesia muncul mushaf-mushaf kontemporer yang memiliki konsep desain, khat, dan tatanan iluminasi yang indah, seperti: Al-Qurean Mushaf Istiqlal, ditulis pada tahun 1991-1995; Al-Qurean Mushaf Sundawi, ditulis pada tahun 1995-1997; Mushaf at-Tin, ditulis pada 1997-1999; dan Mushaf Jakarta, ditulis pada tahun 1999-2000; dan mushaf-mushaf indah lainnya.

\section{Sejarah Penulisan Muṣhậf Al-Qur’ān Akbar di Yayasan Pendidikan Ilmu-ilmu Al- Qur'ān (YPIIQ) Wonosobo}

Pada tahun 1991, di Wonosobo lebih tepatnya di Desa Kalibeber terdapat tempat memproduksi muṣhāf al-Qur'ān tulisan tangan yang berukuran raksasa. Munculnya tradisi menulis muṣhāf al-Qur'ān dengan tangan dan berukuran raksasa ini berangkat dari gagasan $\mathrm{KH}$. Muntaha Al-Hafidz, beliau adalah pengasuh Pondok Pesantren Taḥfiżul Qur'ān (PPTQ) Al-Asy'ariyyah, Kalibeber, Mojotengah, Wonosobo, Jawa Tengah. Kecintaan KH. Muntaha Al-Hafidz terhadap al-Qur'ān yang membuat terealisasikannya proyek penulisan Muṣhāf Al-Qur'ān Akbar. KH. Muntaha Al-Hafidz juga ingin melanjutkan penulisan al-Qur'ān yang sudah pernah ditulis oleh kakeknya, yaitu KH. Abdurrahim (1860-1916 M), beliau disebut sebagai periode perintisan.

KH. Abdurrahim pernah menulis al-Qur'ān ketika perjalanan ibadah haji. Zaman dahulu menunaikan ibadah haji menggunakan kapal laut. Selama perjalanan pergi dan pulang itu beliau menulis al-Qur'ān, namun muṣhāf itu sekarang sudah tidak ada akibat dirusak oleh para penjajah Belanda. Atas dasar peristiwa tersebut, tersirat cita-cita KH. Muntaha Al-Hafidz untuk melestarikan gagasan kakeknya itu. Kemudian KH. Muntaha al-Hafidz merasa bahwa beliau tidak mampu menulis, sehingga beliau menyerahkan tugas itu kepada santrinya, untuk menulis khat dan membuat ornamen tepi atau hiasan (iluminasi).

Lokasi penulisan Muṣhāf Al-Qur'ān Akbar ini berada di Universitas Sains AlQur'an (UNSIQ) Wonosobo, dibawah naungan Yayasan Pendidikan Ilmu-ilmu AlQur'an (YPIIQ) Wonosobo. Total jumlah Muṣhāf Al-Qur'ān Akbar yang ditulis oleh tim penulisan Muṣhāf Al-Qur'ān Akbar sampai sekarang adalah sepuluh muṣhāf dan untuk Muṣhāf Al-Qur'ān Akbar yang ke sebelas sedang dalam proses penulisan. Berikut adalah perinciannya:

Muṣhāf Al-Qur'ān Akbar yang pertama memiliki ukuran 2 x 1,5 meter, waktu penulisan kurang lebih 2,5 tahun. Muṣhāf acuan yang dipakai dalam penulisan Muṣhāf Al-Qur’ān Akbar yang pertama adalah Muṣhāf Kudus. Muṣhāf Al-Qur’ān Akbar yang pertama diberikan kepada Bapak Menteri Penerangan RI pada waktu itu, yaitu Bapak

\footnotetext{
${ }^{29}$ Ali Akbar, "Menggali Khazanah Nusantara: Telaah Ragam Gaya Tulisan dalam Mushaf Kuno", Lektur Keagamaan 2, no. 1, (Jakarta: Puslitbang Lektur Keagamaan, 2004), 60.
} 
H. Harmoko utuk diserahkan kepada Presiden Soeharto yang kemudian disimpan di Binagraha Jakarta (istana negara), lalu dipindahkan ke Baitul Qur'an TMII.

Muṣhāf Al-Qur'ān Akbar yang ke dua memiliki ukuran yang sama dengan muṣhāf yang pertama yaitu 2 x 1,5 meter, lama waktu penulisan 2,5 tahun. Muṣhāf acuan yang dipakai dalam penulisan Muṣhāf Al-Qur'ān Akbar yang kedua juga sama dengan muṣhāe Al-Qur’ān Akbar yang pertama yaitu Muṣhāf Kudus. Muṣ̣āa AlQur'ān Akbar yang kedua diserahkan kepada Pak Tarmizi Tahir selaku Menteri Agama, kemudian disimpan di Baitul Quran TMII.

Muṣhāf Al-Qur'ān Akbar yang ketiga berukuran 1.5 x 1 meter, lama waktu penulisan kurang lebih 2,5 tahun. Muṣhāf acuan yang dipakai dalam penulisan muṣhāf Al-Qur’ān Akbar yang ketiga adalah Muṣhāf Beirut. Muṣhāe ini diserahkan kepada Gubernur DKI Jakarta, Bapak H. Sutiyoso dan kemudian disimpan di Islamic Centre Jakarta.

Muṣhāf Al-Qur'ān Akbar yang keempat berukuran sama dengan yang ketiga yaitu 1,5 x 1 meter, lama waktu penulisan 2 tahun. Muṣhāa acuan yang dipakai dalam penulisan Muṣhāe Al-Qur'ān Akbar yang keempat adalah Muṣ̣̣āf Beirut. Muṣhāf AlQur'ān Akbar yang keempat ini diserahkan kepada ke Gubernur Jawa Tengah yaitu Bapak H. Mardiyanto, kemudian diletakkan di Masjid Agung Jawa Tengah Semarang.

Muṣhāa Al-Qur'ān Akbar yang kelima berukuran ketiga yaitu 1,5 x 1 meter, lama waktu penulisan delapan bulan. Muṣhāf acuan yang dipakai dalam penulisan muṣhāf Al-Qur'ān Akbar yang kelima sama dengan yang ketiga dan keempat yaitu Muṣhāf Beirut. Muṣhāa yang kelima ini diserahkan kepada Sultan Hasanal Bulqiah Brunei Darussalam, kemudian disimpan di Istana Kesultanan Hasanal Bolqiah Brunei.

Muṣhāf Al-Qur'ān Akbar yang keenam memiliki ukuran 1,5 x 1 meter, lama waktu penulisan kurang lebih 1 tahun. Muṣhāa acuan yang dipakai dalam penulisan muṣ̣āâf Al-Qur'ān Akbar yang keenam adalah Muṣhāf Kemenag. Muṣhāf Al-Qur'ān Akbar yang keenam diserahkan kepada Aksa Mahmud Makasar, dan disimpan di Masjid Raya Makassar.

Muṣhāf Al-Qur'ān Akbar yang ketujuh memiliki ukuran 2 x 1,5 meter, lama waktu penulisan kurang lebih 3,5 tahun. Muṣhāf acuan yang dipakai dalam penulisan Muṣhāf Al-Qur'ān Akbar yang ketujuh sama dengan yang keenam, yaitu Muṣhāf Kemenag. Muṣhāf Al-Qur’ān Akbar yang ketujuh diserahkan kepada Bapak Imam Nahrowi selaku Menteri Olahraga RI, kemudian muṣhāf tersebut diismpan di masjid kediaman Bapak Imam Nahrowi.

Muṣhāf Al-Qur'ān Akbar yang kedelapan berukuran 1m x 7cm, lama waktu penulisan kurang lebih 1,5 tahun. Muṣhāf acuan yang dipakai dalam penulisan Muṣhāf Al-Qur'ān Akbar yang kedelapan adalah Muṣhāf Kemenag. Muṣhāf Al-Qur'ān Akbar yang kedelapan diserahkan kepada Bu Sri setiawati yang berkediaman di Depok, dan kemudian muṣhāf tersebut disimpan dikediamannya.

Muṣhāf Al-Qur'ān Akbar yang kesembilan berukuran 2 x 1,5 meter, lama waktu penulisan kurang lebih 1,5 tahun. Muṣhāf acuan yang dipakai dalam penulisan Muṣhāf 
Al-Qur'ān Akbar yang kesembilan adalah Muṣhāf Kemenag. Muṣhāaf Al-Qur'ān Akbar yang kesembilan diserahkan kepada Imam Lapeo dan muṣhāf yang kesembilan tersebut disimpan di Yayasan Masjid Imam Lapeo Poliwali Mandar Sulawesi Barat.

Muṣhāf Al-Qur'ān Akbar yang kesepuluh berukuran 2 x 1,5 meter. Lama waktu penyelesaian kurang lebih tujuh bulan. Muṣhāf Al-Qur'ān Akbar kesepuluh rencananya akan diserahkan kepada Presiden RI yaitu Bapak Jokowi. Muṣhāâ Al-Qur’ān Akbar yang kesepuluh berukuran 2 x 1,5 meter, sekarang masih dalam proses penulisan.

\section{Proses Penulisan Muṣ̣̣āf Al-Qur'ān Akbar}

Dalam menulis Muṣhāf Al-Qur’ān Akbar ini tidak lah sembarangan, karena dibutuhkan ketelitian, keistiqamahan, dan kesabaran. Ada beberapa ketentuanketentuan untuk penulis Muṣhāf Al-Qur'ān Akbar, yaitu saat menulis Al-Qur'ān itu harus dalam keadaan suci, dan saat menulis diiringilah dengan berpuasa kecuali harihari yang diharamkan untuk berpuasa. Sebelum menulis mereka mengawalinya dengan shalat sunnah, memohon kepada Allah agar diberi kekuatan dan keringanan dalam menjalankan amanah dari Kyai mereka tersebut. Ketentuan tersebut juga berdasarkan perintah Kyai mereka.

Penulisan Muṣhāf Al-Qur'ān Akbar dilakukan setiap hari, kecuali kalau sedang berhalangan. Terkadang ada pihak-pihak dari luar yang memesan Muṣhāf Al-Qur'ān Akbar. Biasanya pemesan sebelumnya memesan warna, jenis kertas, ukuran, kemudian setelah clear memberikan tanda jadi atau uang muka terlebih dulu, baru setelah selesai penulisan muṣhāf tersebut, pemesan melunasi kekurangannya. Bahkan tak sedikit dari pemesan itu memberikan tanda hibah yang cukup besar.

Dalam penulisan Muṣhāf Al-Qur'ān Akbar, dibutuhkan alat-alat khusus yang digunakan. Untuk alat-alat, tim penulis sendiri yang memilih dan memesannya. Alatalat tersebut seperti kertas. Kertas yang dipakai untuk penulisan Muṣhāf Al-Qur’ān Akbar adalah art paper 140 gr yang di pesan di PT. Pura Kudus. Kertas ini bertekstur halus, putih, licin, mengkilap, dan tebal. Jenis kertas ini biasa digunakan untuk kartu nama, sampul (cover) buku, poster, dan masih banyak lainnya. Namun bahan kertas yang dipesan ini berbeda dengan kertas art paper pada umumnya, karena bahan kertas ini dipesan khusus agar ukurannya pas dan tinta bisa meresap dengan baik. Jenis kertas art paper 140 gr sudah dipertimbangkan oleh tim penulisan Muṣhāf Al-Qur’ān Akbar untuk menghindari hal-hal yang tak diinginkan, sebab kualitas kertas sangat lah mempengaruhi hasil tulisannya.

Selain kualiatas kertas yang diperhatikan, keberadaan pena sebagai alat tulisnya tidak kalah pentingnya. Pena, untuk penulisan khat menggunakan pena yang terbuat dari bambu wuluh atau kayu andam. Selain itu bisa juga menggunakan bolpoin untuk kaligrafi yang sekarang sudah mulai beredar banyak di pasaran. Tinta yang dipakai untuk menulis khat menggunakan tinta yang tahan air, sehingga ketika muṣhāf terkena air dipastikan tidak luntur

Meja untuk menulis khat, meja yang digunkan untuk menulis khat bukanlah meja seperti biasanya, bentuknya cukup berbeda. Meja tersebut dipesan sendiri kepada 
tukangnya. Sekarang meja yang tersedia khusus untuk tempat menulis sudah ada tiga buah dengan ukuran yang berbeda, ada yang berukuran $221 \mathrm{~cm}$ x $169 \mathrm{~cm}$, dan ada yang berukuran lebih kecil yaitu ukuran $170 \mathrm{~cm}$ x $110 \mathrm{~cm}$. Meja yang khusus untuk menulis berbentuk persegi empat dan ada lacinya tempat untuk menyimpan yang sudah jadi tulisan, kemudian bagian atasnya agak menurun sedikit tempat untuk mendekatkan penulis. Selain beberapa peralatan di atas, tak kalah pentingnya dalam penulisan Muṣhāf Al-Qur'ān Akbar tersebut adalah alat sablon. Alat sablon tersebut seperti film sablon, screen, rakel, tinta sablon, meja afdruk, dan emulsi/obat afdruk.

Setelah semua alat terkumpul, penulisan muṣhāa Al-Qur'ān Akbar pun bisa dilakukan. Sebelum melakukan penulisan, kertas yang akan digunakan menulis itu terlebih dahulu di sablon. Dan pada saat penyblonan juga masih mengukur untuk menentukan mana yang untuk penjilidan, mana halaman ganjil-genap, dan sebagainya. Setelah di sablon, kertas-kertas itu digarisi pakai penggaris khusus biasanya berbentuk kertas tebal yang sudah dibentuk, jadi tinggal memasang dan menyesuaikan dengan posisi kertas yang akan digarisi. Kertas digarisi menjadi lima belas baris bolak-balik. Setelah garis selesai barulah menulis dimulai dengan membuat sketsa terlebih dahulu meggunakan pensil $2 \mathrm{~b}$. Lalu dilakaukan lah pentashihan bacaan, jika sudah tidak ada yang salah maka dilanjutkan kepada proses penulisan menggunakan tinta. Setelah proses penulisan selesai 30 juz maka dilakukan pentashihan kembali bahkan sampai berulang-ulang untuk memastikan sudah benar-benar tidak ada kesalahan. Kemudian diteruskan ke proses yang selanjutnya yaitu penjilidan. Lembaran-lembaran Muṣḥāf Al-Qur'ān Akbar dihimpun per-juz, agar mudah saat penggabungan. Bahan dasar yang dipakai untuk menjilid adalah oscar, yaitu bahan sintesis yang menyerupai kulit. Oscar dipilih karena tingkat ketahanan dan keawetan bahannya bisa untuk jangka waktu lama.

\section{Karakteristik Muṣ̣āf Al-Qur'ān Akbar}

Setiap karya yang dibuat oleh seseorang pasti mempunyai ciri khas tersendiri, sama halnya dengan Muṣhāf Al-Qur'ān Akbar ini. Mulai dari jenis rasm, jenis rasm yang dipakai dalam penulisan Muṣhāf Al-Qur'ān Akbar merujuk pada penulisan rasm 'Uśmani. Dalam penulisan kata atau ungkasan berbahasa Arab, dikenal ada tiga bentuk tulisan yaitu al-Rasm al-Qiyasi, al-Rasm al-'arudi, dan al-Rasm al-'Uśmani. Al-Rasm al-'Usmani merupakan cara penulisan kata dalam al-Qur'ān yang disetujui oleh khalifah 'Usman ketika penghimpunan al-Qur'ān. Rasm ini memiliki karakter khusus yang berbeda dengan tulisan yang lain terlebih dengan al-rasm al-qiyasi/al-rasm alistilahi/al-rasm al-imla' ${ }^{30}{ }^{30}$

Dalam penulisan kaligrafi Arab terdapat beberapa jenis khat, seperti khat kufi, khat naskhi, khat tsulutsi, khat faritsi, khat riq'ah, khat diwani, khat diwani jali, dan khat ijazah. Dari semua jenis khat di atas, khat naskhi lah yang dipilih dalam penulisan Muṣhāf Al-Qur'ān Akbar. Jenis khat ini dipilih karena lebih dikenal oleh

\footnotetext{
${ }^{30}$ Nur Mahmudah, Tashih Mushaf (Kudus: Sekolah Tinggi Agama Islam Negeri (STAIN) Kudus, 2011), 7-8.
} 
masyarakat Indonesia. Khath naskhi juga merupakan salah satu khat yang biasa digunakan dalam penulisan muṣhāf al-Qur'ān pada umumnya karena bentuk dari khat naskhi mudah dibaca dan ditulis. Sedangkan untuk penulisan nama surat menggunakan khat tsulutsi.

Pada sebuah naskah, iluminasi memiliki kedudukan yang sangat penting, sebab iluminasi menjadi media estetika dan sarana eksplanatori bagi teks yang terdapat dalam naskah. Iluminasi juga membantu penjelasan naskah tersebut berasal. Sebab kecenderungan style motif tiap daerah memiliki karakter masing-masing, selain subjektivitas pembuatnya. Iluminasi juga dapat membantu menentukan kapan naskah tersebut ditulis atau disalin, sebab seniman-seniman pembuat iluminasi tersebut merupakan saksi zaman, dan setiap zaman memiliki style yang berbeda. ${ }^{31}$ Iluminasi atau ornamen di Muṣhāf Al-Qur'ān Akbar dari awal hingga akhir berbeda-beda. Muṣhāf yang pertama iluminasinya full color menggunakan ornamen 'arobiyah, namun bagian dalamnya tidak full color perpaduan antara daun dan ornamen 'arobi. Muṣhāf yang kedua, iluminasinya juga full color perpaduan antara khat diwani dengan tulisan Al-Asy'ariyyah, kemudian yang bagian dalam tidak full color perpaduan antara khat kufi dengan dipadukan tulisan Al-Asy'ariyyah. Muṣhāf yang ketiga, iluminasi bagian luarnya sama dengan muṣhāf yang pertama dan yang kedua yaitu full color, tetapi yang bagaian dalam sama dengan muṣhāf yang pertama. Muṣhāf yang keempat, iluminasi bagian luarnya sama dengan muṣhāf yang kedua yaitu full color, tetapi yang bagian dalamnya perpaduan antara khat kufi dengan tulisan UNSIQ. Muṣhāf yang kelima, iluminasi yang bagian luarnya sama dengan muṣhāf-muṣhāf yang sebelumnya namun ditambah dengan logo Brunei dan logo UNSIQ. Sedang bagian dalamnya perpaduan antara khat kufi dan logo Brunei. Muṣhāf yang keenam, bagian luarnya sama dengan muṣhāf yang kelima, hanya saja tidak ada logo Brunei, tetapi diganti dengan logo UNSIQ di keempat sudutnya. Bagian dalam pun sama dengan yang kelima, tetapi tidak ada logo Bruneinya. Muṣhāf yang ketujuh dan yang ke delapan iluminasi bagian luar maupun bagian dalam sama dengan muṣhāf yang keenam. Kemudian muṣhāf yang kesembilan sama dengan yang sebelumnya tetapi yang bagian luar dan dalam ditambah dengan logo Masjid Nurut Taubah. Dan muṣ̣āf yang kesepuluh sama juga dengan yang sebelum-sebelumnya.

Dalam segi layout, penulisan Muṣhāf Al-Qur'ān Akbar di halaman pertama (surah al-Fatihah dan awal surah al-Baqarah) terdiri dari enam baris. Pada halaman selanjutnya, setiap halaman terdiri dari 15 baris. Tiap baris akhir ditutup dengan akhir ayat atau lebih dikenal dengan muṣhāf pojok. Layout pada muṣhāf pertama sampai kesepuluh tidak ada yang berbeda.

\section{Motivasi Penulisan Muṣḥ̄ā Al-Qur'ān Akbar}

Adanya penulisan muṣhāe Al-Qur'ān Akbar sampai sekarang pastilah ada alasan dan faktor tertentu. Faktor tersebut adalah yang pertama ta'dzim kepada sang Kyai.

\footnotetext{
${ }^{31}$ Alfian Rokhmansyah, Teeori Filologi, (2018), 56-57
} 
Secara terminologis, kyai adalah pendiri dan pemimpin sebuah pesantren yang sebagai muslim "terpelajar" yang telah membaktikan hidupnya demi Allah serta menyebarluaskan dan mendalami ajaran-ajaran dan pandangan Islam melalui kegiatan pendidikan Islam. Namun pada umumnya di masyarakat, kata "kyai" disejajarkan dengan ulama dalam khazanah Islam, malahan yang disebut pertama lebih populer di kalangan awwam al-muslimin, yaitu orang-orang yang memiliki pengetahuan yang disinyalir oleh al-Qur'ān sebagai hamba-hamba Allah yang paling takut, dan orangorang yang menjadi pewaris sah para nabi. ${ }^{32}$ Dengan kemampuan-kemampuan luar biasa mengenai ilmu Islam yang dimiliki oleh seorang kyai, membuat ia sangat dihormati oleh masyarakat sekitarnya. Karisma yang ia miliki, mampu menarik orangorang untuk belajar dan mendalami Islam kepada kyai.

Menurut Max Weber - salah satu ahli sosiologi terkemuka - istilah 'karisma' akan diterapkan pada suatu mutu tertentu yang terdapat pada kepribadian seseorang, yang karenanya dia terpisah dari orang biasa dan diperlakukan sebagai orang yang dianugerahi dengan kekuasaan atau mutu yang bersifat adiduniawi, luar biasa, atau sekurang-kurangnya merupakan kekecualian dalam hal-hal tertetu. Mutu seperti itu menarik para pengikut yang setia pada pemimpin karismatik secara pribadi dan yang memiliki komitmen terhadap keteraturan normatif atau moral yang digambarkannya. Menurut tipologi tindakan sosial yang sudah didiskusikan, kepatuhan para pengikut tergantung baik pada identifikasi emosional dengan pemimpin itu sebagai seorang pribadi maupun pada komitmen terhadap nilai-nilai absolut yang diajarkannya itu.

KH. Muntaha al-Hafidz merupakan seorang kyai yang luar biasa. Karisma KH. Munataha al-Hafidz di lingkungan pesantren maupun dihadapan masyarakat luas sangat besar. Hal ini dikarenakan beliau memiliki kualitas spiritual yang tinggi lantaran kecintaan dan pengalamannya terhadap isi al-Qur'ān yang sangat baik. Hal ini juga dibuktikan dengan hasil-hasil karya gagasan beliau yang selalu mengutamakan al-Qur'ān .

$$
\text { ما وصل من بان طالب العلم لاينال العلم ولا ينتفع به الابتعظيم العلم واهله وتعظم الاستاذ وتوقيره. قيل: }
$$

Terjemahan: "Ketahuilah bahwa seorang yang mencari ilmu tidak akan mendapat ilmu dan tidak akan manfaat dari ilmunya kecuali dengan mengagungkan ilmu dan orang-orang yang berilmu, mengagungkan dan menghormati guru, seperti yang dikatakan: Tidaklah seseorang mencapai keberhasilan melainkan dengan penghormatan dan tidaklah seorang mengalami kegagalan melainkan iakarena ia tidak hormat."34

\footnotetext{
${ }^{32}$ Moch. Eksan, Kiai Kelana: Biografi KH. Muchith Muzadi (Yogyakarta: LkiS, 2000), 1-2.

${ }^{33}$ Imam Burhanul Islam Azzarnuji, Ta'limul Muta'alim, terj. Achmad Sunarto (Surabaya: al-Miftah), 55.

34 Azzarnuji, 70.
} 
Sedang faktor yang kedua adalah karena keinginan untuk memuliakan al-Qur'ān yang sangat besar. Tidak dapat disangkal oleh siapapun bahwa kitab suci al-Qur'ān memiliki keistimewaan-keistimewaan. Keagungan dan kesempurnaan al-Qur'ān bukan hanya diketahui atau dirasakan oleh mereka yang memercayai dan mengharapkan petunjuk-petunjuknya, melainkan juga oleh semua orang yang mengenal dekat alQur'ān . Karena, tiada sesuatu bacaan pun - sejak manusia mengenal baca-tulis sekitar lima ribu tahun yang lalu - yang keadaannya sama dengan al-Qur'ān , bacaan yang amat sempurna lagi mulia itu. ${ }^{35}$

Al-Qur'ān merupakan merupakan mukjizat yang luar biasa bagi umat Islam. Sesuatu yang berhubungan dengan al-Qur'ān pun akan menjadi ikut mulia. Al-Qur'ān diturunkan pada bulan Ramadhan, bulan tersebut pun menjadi bulan yang paling mulia di antar bulan lainnya. Kemudian malam di mana diturunkannya al-Qur'ān pun menjadi malam yang sangat mulia, yaitu malam lailatul qadr.

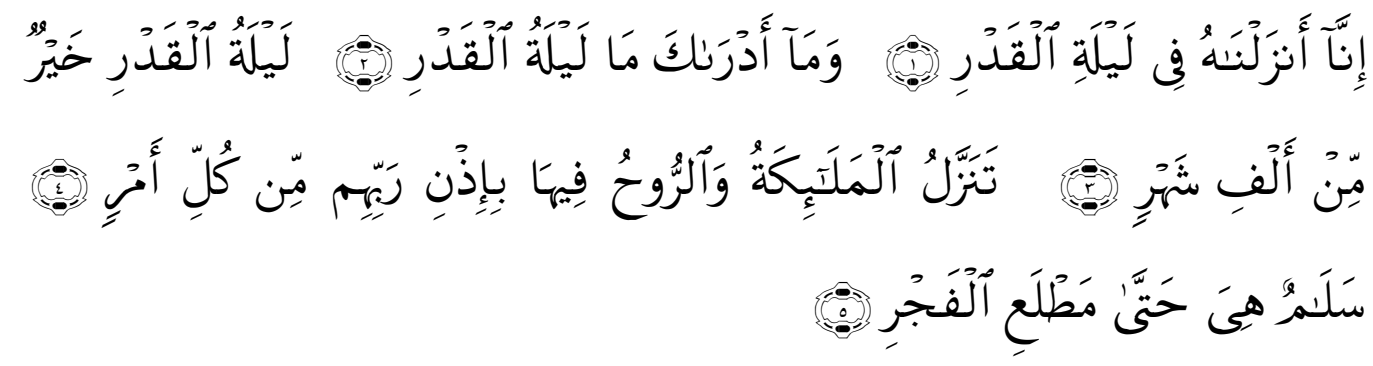

Terjemahan "Sesungguhnya Kami telah menurunkannya (al-Quran) pada malam kemuliaan. Dan tahukah kamu apakah malam kemuliaan itu?. Malam kemuliaan itu lebih baik dari seribu bulan. Pada malam itu turun malaikat-malaikat dan Malaikat Jibril dengan izin Tuhannya untuk mengatur segala urusan. Malam itu (penuh) Kesejahteraan sampai terbit fajar" ${ }^{36}$

Allah Ta'ala memberitahukan bahwa Dia menurunkan Al-Qur'ān pada waktu lailatul qadr, yaitu satu malam yang penuh berkah, yang oleh Allah difirmankan:

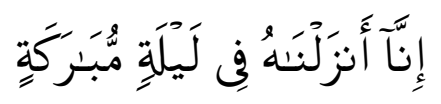

Terjemahan: "Sesungguhnya Kami telah menurunkan Al-Qur'ān pada suatu malam yang penuh berkah" 37

Dan itulah malam lailatul qadr yang ada pada bulan Ramadhan, sebagaimana yang difirmankan Allah Ta'ala:

${ }^{35}$ Quraish Shihab, Mukjizat Alquran: ditinjaun dari Aspek Kebahasaan, Isyarat Ilmiah, dan Pemberitaan Ghaib, Cet. III (Bandung: Mizan, 2013), 50.

${ }^{36}$ Q.S. Al-Qadr [97]: 1-5.

${ }^{37}$ Q.S. Ad-Dukhan [44]:3. 


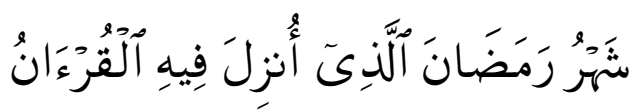

Terjemahan: "Bulan Ramadhan, bulan yang di dalamnya diturunkan Al-Qur'ān ". 38

Selanjutnya, dengan mengagungkan keberadaan lailatul qadryang Dia khususkan dengan penurunan Al-Qur'ān al-'Adzhim padanya, Allah Ta'ala berfirman:

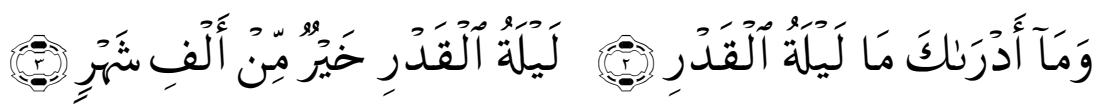

Terjemahan: "Dan tahukah kamu apakah malam kemuliaan itu? Malam kemuliaan itu lebih baik dari seribu bulan". Ketika malam kemuliaan itu menyerupai ibadah selama seribu bulan, maka ditegaskan di dalam kitab ashShahihain dari Abu Hurairah, bahwa Rasulullah SAW bersabda:

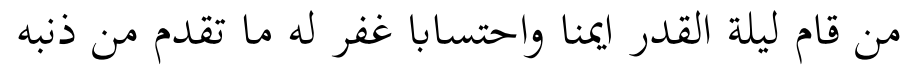

Terjemahan: "Barangsiapa yang bangun pada malam kemuliaan (lailatul qadr) dengan pebuh keimanan dan pengharapan akan pahala maka akan diberikan ampunan kepadanya atas dosa-dosanya yang telah lalu"

Dan firman A1llah Ta'ala:

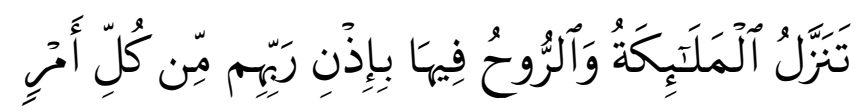

"Pada malam itu turun malaikat-malaikat dan malaikat Jibril dengan izin Rabbnya untuk mengatur segala urusan". Yakni, banyak turunnya para malaikat ini karena banyaknya berkah yang terdapat padanya. Dan para malaikat utu selalu turun bersamaan dengan turunya berkah, sebagaimana mereka senang untuk turun saat alQur'ān dibaca. Selain itu, para malaikat ini akan mengelilingi halaqah-halaqah dzikir (majelis ilmu) dan meletakkan sayap mereka bagi pencari ilmu dengan penuh kejujuran, sebagai bentuk penghormatan terhadapnya.

Sa'id bin Mnashur berkata: "Isa bin Yunus memberitahu kami, al-A'masy memberitahu kami, dari Mujahid, mengenai firman-Nya:

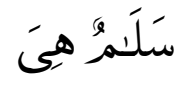

"Malam itu (penuh) kesejahteraan," dia mengatakan: "Ia aman, di mana pada waktu itu syaitan tidak dapat melakukan kejahatan atau melancarkan gangguan". Sedangkan Qatadah dan lain-lain mengatakan: "Pada waktu itu semua urusan diputuskan, berbagai ajal dan rizki juga ditetapkan, sebagaimana yang difirmankan Allah Ta'ala:

\footnotetext{
${ }^{38}$ QS. Al-Baqarah [2]: 185.
} 


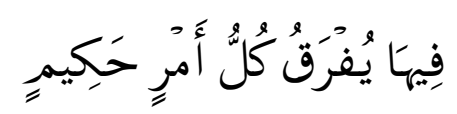

Terjemahan: "Pada malam itu dijelaskan segala urusan yang penuh hikmah" (QS. AdDukhan [44]: 4). ${ }^{39}$

\section{Penutup}

Dari pemaparan di atas dapat disimpulkan bahwa penulisan Muṣhāf Al-Qur'ān Akbar di Yayasan Pendidikan Ilmu-ilmu Al-Qur'ān (YPIIQ) Wonosobo merupakan salah satu upaya untuk membuat hidup dan menghidupkan al-Qur'ān oleh masyarakat, dalam arti respons sosial (realitas) terhadap al-Qur'ān. Adanya penyalinan al-Qur'ān meggunakan tulis tangan juga merupakan bentuk pelestarian al-Qur'ān mulai dari penyampaian, penghafalan, penulisan, standarisasi, dan pencetakan.

Setiap karya tidaklah berangkat dari ruang kosong, tentu ada sebab musababnya. Adanya tradisi penulisan Muṣhāf Al-Qur'ān Akbar di Yayasan Pendidikan Ilmu-ilmu Al-Qur'an (YPIIQ) Wonosobo merupakan buah hasil dari kegigihan dan keistiqamahan seorang murid dalam menjaga amanah gurunya.

Selain itu, kecintaan sang penulis terhadap Al-Qur'ān juga menjadi faktor pendorongnya. Nilai keindahan muṣhāf al-Qur'ān yang dapat dilihat dari khat /kaligrafi, iluminasi, kolofon, dan juga watermark pada kertas, merupakan salah satu upaya penulis untuk takrim Al-Qur'ān (pemuliaan Al-Qur'ān ). Pesan utama yang dapat dilihat dari masing-masing muṣhāf al-Qur'ān adalah cerminan (secara tidak langsung) dari keinginan penulis/penerbit memunculkan daya tarik tersendiri melalui unsur-unsur estetika di atas.

\section{DAFTAR PUSTAKA}

Abdillah, Aam Billy Muhammad Rodibillah, Ajid Thohir, "Sejarah Penulisan AlQur'an Mushaf Sundawi Di Bandung Tahun 1995-1997," Historia Madania Jurnal Ilmu Sejarah 2, no. 2 (2018): 25-52.

Akbar, Ali. "Pencetakan Mushaf Al-Qur'an Di Indonesia." SUHUF 4 (2011). https://www.researchgate.net/publication/305143831_Pencetakan_Mushaf_Al -Qur'an_di_Indonesia full Text FileContent

Akbar, Ali, "Menggali Khazanah Nusantara: Telaah Ragam Gaya Tulisan dalam Mushaf Kuno", Lektur Keagamaan, Vol. 2, No. 1, (Jakarta: Puslitbang Lektur Keagamaan, 2004)

Chaer, Abdul. Perkenalan Awal dengan Al-Qur'an. Jakarta: Rineke Cipta, 2014.

\footnotetext{
${ }^{39}$ Abdullah bin Muhammad bin Abdurahman bin Ishaq Al-Sheikh, Tafsir Ibnu Katsir, Jilid. 8, terj. M. Abdul Ghoffar dan Abu Ihsan Al-Atsari (Bogor: Pustaka Imam Asy-Syafi'i, 2014), 509-510.
} 
Departemen Agama RI. Mukadimah Al-Qur'an dan Tafsirnya. Jakarta: Departemen Agma RI, 2008.

Efendi, Nur dan Fathurrohman, Muhammad. Studi Al-Qur'an: Memahami Wahyu Allah secara Lebih Integral dan Komprehensif. Yogyakarta: Teras, 2014.

Eksan, Moch. Kiai Kelana: Biografi KH. Muchith Muzadi (Yogyakarta: LkiS, 2000.

Esack, Farid Samudera al-Qur'an. Yogyakarta: DIVA Press, 2007.

Hitami, Munzir. Pengantar Studi Al-Qur'an:Teori dan Pendekatan. Yogyakarta: LKiS, 2012.

Lestari, Lenni. "Mushaf Al-Qur'an Nusantara: Perpaduan Islam Dan Budaya Lokal." Jurnal At-Tibyan: Jurnal Ilmu Alqur'an dan Tarsir 1 no.1 (2016): 173-195.

Mahmudah, Nur. Tashih Muṣhāf. Kudus: Sekolah Tinggi Agama Islam Negeri (STAIN) Kudus, 2011.

Nasruddin, "Sejarah Penulisan Alquran (Kajian Antropologi Budaya)" Rihlah 2 no. 1 (Mei 2015), https://doi.org/10.24252/rihlah.v2i01.1360

Pahlevi, Reza. "Dakwah Kultural Bayt Al-Qur'an Al-Akbar Ukiran Kayu Khas Melayu Palembang," Intizar 22, no. 1 (2016): 173-197, https://doi.org/10.19109/intizar.v22i1.548.

Rodibillah, Billy Muhammad, Ajid Thohir, Aam Abdillah. "Sejarah Penulisan AlQur'an Mushaf Sundawi Di Bandung Tahun 1995-1997.” Historia Madania Jurnal Ilmu Sejarah 2, no. 2 (2018): 25-52.

Rokhmansyah, Alfian. Teeori Filologi. 2018

Saidah dan Kalimatul 'Ulya, "Rijalul Qur'an : Membincang Sejarah Para Penulis Wahyu”, QOF 1 no.1 (Januari 2017), https://doi.org/10.30762/ qof.v1i1.929

Shihab, Quraish. Membumikan Al-Qur'an. Bandung: Mizan Pustaka, 1994.

Shihab, Quraish. Mukjizat Al-Qur'ān : ditinjaun dari Aspek Kebahasaan, Isyarat Ilmiah, dan Pemberitaan Ghaib. Cet. III. Bandung: Mizan, 2013.

Suhadi, Ulumul Qur'an. Kudus: Nora Media Enterprise, 2011.

Sudrajat, Enang. "Pentashihan Mushaf Al-Qur'an Di Indonesia." SUHUF6 (2013).

Syamsuddin, Sahiron. Metodologi Penelitian Living Qur'am dan Hadis. Yogyakarta: TH-Teras, 2007. 